\title{
Influence of Calcium Content of Tissue on Hyperhydricity and Shoot-Tip Necrosis of in vitro Regenerated Shoots of Lavandula angustifolia Mill.
}

\author{
Marília Pereira Machado ${ }^{1 *}$, André Luís Lopes da Silva ${ }^{2}$, Luiz Antonio Biasi ${ }^{1}$, Cícero \\ Deschamps $^{1}$, João Carlos Bespalhok Filho ${ }^{1}$ and Flávio Zanette ${ }^{1}$ \\ ${ }^{1}$ Departamento de Fitotecnia e Fitossanitarismo; Setor de Ciências Agrárias; Universidade Federal do Paraná; \\ Curitiba - PR - Brasil. ${ }^{2}$ Departamento de Engenharia de Bioprocessos e Biotecnologia; Universidade Federal do \\ Paraná; Curitiba - PR - Brasil
}

\begin{abstract}
In the present study, the effects of two $\mathrm{CaCl}_{2} \cdot 2 \mathrm{H}_{2} \mathrm{O}$ levels (440 and $1320 \mathrm{mg} \mathrm{L}^{-1}$ ) and two subcultures were evaluated on in vitro shoots of Lavandula angustifolia $c v$. Provence Blue. $\mathrm{Ca}^{2+}$ content of the apical, middle and basal portion of shoots was determined. Increasing $\mathrm{CaCl}_{2} \cdot 2 \mathrm{H}_{2} \mathrm{O}$ level in the culture medium increased tissue $\mathrm{Ca}^{2+}$ content and $^{2}$ decreased hyperhydricity. Shoot-tip necrosis also decreased with $1320 \mathrm{mg} \mathrm{L}^{-1} \mathrm{CaCl}_{2} \cdot 2 \mathrm{H}_{2} \mathrm{O}$, but it did not occur in the second subculture. The middle and basal portion had higher $\mathrm{Ca}^{2+}$ content than apical portion. In nonhyperhydric tissues, there were smaller and more juxtaposed cells. Scanning electron microscopy of the leaves demonstrated that trichomes from in vitro leaf surface occurred in smaller quantities.
\end{abstract}

Key words: True lavender, Micropropagation, $\mathrm{CaCl}_{2} \cdot 2 \mathrm{H}_{2} \mathrm{O}$, Leaf anatomy, Ultrastructure, Trichome

\section{INTRODUCTION}

Lavandula angustifolia Mill. (syn. L. officinalis Chaix; L. vera DC.) is a plant belonging to the Lamiaceae family. Essential oil obtained from the flowers of $L$. angustifolia is composed mainly of linalyl acetate, linalool, lavandulol, 1,8-cineole, lavandulyl acetate and camphor (Lis-Balchin and Hart 1999). Lavender is one of the most useful medicinal plants and has found wide application in perfumes and cosmetics. L. angustifolia may be propagated sexually or asexually. Reproduction via seeds is usually slow and the plants display a great variation in a number of characteristics such as growth rate and essential oil composition. Therefore, vegetative propagation is the most effective to produce a large number of uniform individuals displaying a genotype of interest.

Tissue culture techniques have been applied to Lavandula plants (Quazi 1980; Calvo and Segura 1989; Jordan et al. 1990; Gras and Calvo 1996; Andrade et al. 1999; Echeverrigaray et al. 2005; Zuzarte et al. 2010; Machado et al. 2011; Silva et al. 2013). However, the performance and survival of in vitro cultures of many plant species are often hampered by the phenomenon of hyperhydricity (Debergh et al. 1992), including lavender species. Hyperhydricity can lead to irreversible loss of regenerative ability of the tissue (Gaspar et al. 2000) and other detrimental changes, and ultimately death. These losses, together with the poor survival rate of hyperhydric shoot when transferred to ex vitro conditions, limit the

*Author for correspondence: ma_rilia10@hotmail.com 
potential of in vitro techniques for mass propagation. In general, the leaves of hyperhydric shoots are thicker, elongated, wrinkled and/or curled, and can be brittle when compared to normal leaves. Anatomical characteristics change in hyperhydric shoots and several types of abnormal structures can be recognized (Ziv 1991). Several factors can induce the hyperhydricity in explants, such as high BAP levels (Oliveira et al. 2010), cultivar (Carvalho et al. 2013), and agar concentration (Abdoli et al. 2007) but the most common cause of the hyperhydricity occurrence is the culture in liquid medium (Scheidt et al. 2011; Silva et al. 2012). Some species are so sensitive to this physiological change that even when cultivated in solid medium with a low BAP level, hyperhydricity occurs, as it is the case for $L$. angustifolia. In this context, one of the strategies to overcome this problem is the modification of the composition of the culture medium.

$\mathrm{Ca}^{2+}$ concentration in the culture medium has been associated with the shoot-tip necrosis, which decreases when the calcium content increases in the medium for in vitro culture of Castanea mollissima, $C$. dentata and C. sativa (Qiguang et al. 1985; Piagnani et al. 1996). Calcium is an integral component in the cell wall and plays an important role in maintaining membrane integrity (Marschner 1995; Machado et al. 2010). This study investigated the relationship between tissue $\mathrm{Ca}^{2+}$ content in the reduction of hyperhydricity and shoot-tip necrosis. The leaf anatomy in nonhyperhydric and hyperhydric common lavender was investigated to identify the structural alterations related with this phenomenon.

\section{MATERIALS AND METHODS}

\section{Plant material and source of explants}

Shoot-tips (approximately $5 \mathrm{~mm}$ ) from $L$. angustifolia Mill. cv. Provence Blue were surface sterilized by immersion in $70 \%$ ethanol for 20 seconds, followed by immersion in $1 \%$ sodium hypochlorite containing two drops of Tween-20 ${ }^{\circledR}$ per $100 \mathrm{~mL}$ for $20 \mathrm{~min}$ under manual agitation, followed by three rinses in distilled and autoclaved water. Explants were incubated on MS medium (Murashige and Skoog 1962) containing 3\% sucrose, $0.6 \%$ agar $\left(\operatorname{Vetec}^{\circledR}\right)$ and the $\mathrm{pH}$ was adjusted to 5.8. After five weeks, the explants presented greening shoots. The shoot multiplication was carried out on MS medium containing 3\% sucrose, $0.6 \%$ agar $\left(\right.$ Vetec $\left.^{\circledR}\right)$ and supplemented with $1.0 \mu \mathrm{M}$ 6-benzylaminopurine (BAP) at each 40 days (subcultures). The culture flasks (60 x $90 \mathrm{~mm}$ and $200 \mathrm{~mL}$ volume) were used as culture vessels and were sealed by polypropylene autoclavable lids. Each culture flask contained $20 \mathrm{~mL}$ culture medium. Voucher specimens (adult plant) have been deposited at the Herbarium of Federal University of Paraná (UFPR) under code numbers UPCB 61303.

\section{$\mathrm{Ca}^{2+}$ treatments}

Shoots $(2.0 \mathrm{~cm}$ length) from in vitro multiplication (methodology described above) were used as explants. The basal medium was MS containing $3 \%$ sucrose and solidified with $0.6 \%$ agar $\left(\right.$ Vetec $\left.^{\circledR}\right)$. The treatments consisted of two calcium levels: 440 (MS standard concentration) and 1320 mg L ${ }^{-1} \mathrm{CaCl}_{2} \cdot 2 \mathrm{H}_{2} \mathrm{O}$ (Machado et al. 2010). The results of two subcultures, carried out every $40 \mathrm{~d}$, were compared. The shoot length $(\mathrm{cm})$, number of leaves, shoot number per explant, rooting (\%), apical necrosis $(\%)$ and hyperhydricity $(\%)$ were evaluated at the end of each subculture.

\section{Determination of $\mathrm{Ca}^{2+}$ content}

After second subculture, shoots were cut into apical, middle and basal portion, washed, dried and ground. Calcium was separated from the sample tissues by nitropercloric digestion and calcium content was determined by EDTA chelatometry methodology (Malavolta et al. 1997).

\section{Histological analysis}

Leaves (completely expanded) were collected at the second node and fixed in $70 \%$ FAA $(5.0 \mathrm{~mL}$ $40 \%$ formaldehyde, $90 \mathrm{~mL} 70 \%$ alcohol and 5.0 $\mathrm{mL}$ acetic acid) during $72 \mathrm{~h}$ (Johansen 1940). After this, the material was transferred into $70 \%$ ethanol and dehydrated in an ethanol series. The samples were then embedded in glycol methacrylate (GMA) following the procedure described by Feder and O'Brien (1968) and the manufacturer's instructions (JB - PolyScience ${ }^{\circledR}$ ). After the GMA inclusion, sections were performed with a rotary microtome with steel razor type C, giving a thickness of $7 \mu \mathrm{m}$. The cuttings were disposed in the slides and stained with $0.05 \%$ toluidine blue for $10 \mathrm{~min}$ (O'Brien et al. 1964). Then the slides were washed under tap water for approximately $5 \mathrm{~min}$, dried and mounted in synthetic resin $\left(\right.$ Entelan $\left.^{\circledR}\right)$. The pictures were made with digital camera under microscope (Olympus $\left.{ }^{\circledR}\right)$. 


\section{Scanning electron microscopy}

Leaf samples were collected at the second completely expanded leaves from in vitro grown (40 days-old, in the first subculture) normal and hyperhydric plants obtained from independent regeneration events. Samples were dehydrated in a routine, graded ethanol series. Leaf samples were critical-pointed-dried with $\mathrm{CO}_{2}$ using a Balzer's Critical Point Dryer (Bal-Tec CPD 030) and fragments were positioned on stubs prior to gold sputtering in a Sputter Coater (Balzers union FL 9496 SCD 030). The specimens were observed and micrographed using a JEOL (JSM 6360 LV) $\mathrm{SEM}$ at $15 \mathrm{kV}$.

\section{Culture conditions and statistical analysis}

Cultures were incubated at $25 \pm 2{ }^{\circ} \mathrm{C}$ under a light intensity of $30 \mu \mathrm{M} \mathrm{m}^{-2} \mathrm{~s}^{-1}$ obtained with white fluorescent lamps and a $16 \mathrm{~h}$ photoperiod. The experimental design was a randomized complete block in a two-way factorial arrangement $(2 \times 2)$ with four replicates of 40 explants per treatment. The data was submitted to a normality analysis by the Lilliefors's method, followed by the analysis of variance (ANOVA), followed by the Duncan's multiple range test with the level of significance
$P \leq 0.05$. The variables from the counting were transformed to $\sqrt{x+0.5}$ and variables from the percentages were transformed to $\arcsin \sqrt{x / 100}$.

\section{RESULTS AND DISCUSSION}

There was no interaction between the two factors, $\mathrm{CaCl}_{2} \cdot 2 \mathrm{H}_{2} \mathrm{O}$ concentrations and subcultures on in vitro multiplication of $L$. angustifolia cv. Provence Blue for all the variables evaluated (Table 1). Shoot length, number of leaves, shoot number per explants and percentage of rooting were not significantly influenced by $\mathrm{CaCl}_{2} \cdot 2 \mathrm{H}_{2} \mathrm{O}$ concentration used. Nevertheless, shoot-tip necrosis and hyperhydricity percentage showed significant differences in the shoots cultivated with different $\mathrm{CaCl}_{2} \cdot 2 \mathrm{H}_{2} \mathrm{O}$ concentrations. The concentration of $1320 \mathrm{mg} . \mathrm{L}^{-1} \mathrm{CaCl}_{2} \cdot 2 \mathrm{H}_{2} \mathrm{O}$ was beneficial for in vitro shoots of $L$. angustifolia, which decreased the occurrence of hyperhydricity and shoot-tip necrosis (Table 1). Despite high levels of the $\mathrm{CaCl}_{2} \cdot 2 \mathrm{H}_{2} \mathrm{O}$ in $\mathrm{MS}$ medium there were leaf yellowing, weak stems and even death of tissues because of chloride toxicity (McCown and Sellmer 1987).

Table 1 - Effect of $\mathrm{CaCl}_{2} \cdot 2 \mathrm{H}_{2} \mathrm{O}$ concentrations during two subcultures on in vitro multiplication of Lavandula angustifolia $\mathrm{cv}$. Provence Blue.

\begin{tabular}{|c|c|c|c|c|c|}
\hline \multirow{2}{*}{$\begin{array}{c}\mathrm{CaCl}_{2} \cdot 2 \mathrm{H}_{2} \mathrm{O} \\
\left(\mathrm{mg} \mathrm{L}^{-1}\right)\end{array}$} & \multirow[b]{2}{*}{ Subculture first } & \multirow[b]{2}{*}{$\begin{array}{l}\text { Subculture } \\
\text { second }\end{array}$} & \multicolumn{3}{|c|}{$F$-test } \\
\hline & & & $\mathrm{CaCl}_{2} \cdot 2 \mathrm{H}_{2} \mathrm{O}$ & Subculture & $\begin{array}{c}\mathrm{CaCl}_{2} .2 \mathrm{H}_{2} \mathrm{O} \times \\
\text { Subculture }\end{array}$ \\
\hline & Shoot length $(\mathrm{cm})$ & & & & \\
\hline 440 & $1.9_{( \pm 0.14)}$ & $3.0_{( \pm 0.40)}$ & ns & $P \leq 0.05$ & ns \\
\hline 1320 & $2.0_{( \pm 0.53)}$ & $3.0_{( \pm 0.23)}$ & & & \\
\hline & Number of leaves & & & & \\
\hline 440 & $11.1_{( \pm 0.80)}$ & $12.6_{( \pm 1.56)}$ & ns & ns & ns \\
\hline 1320 & $11.0_{( \pm 1.40)}$ & $11.1_{( \pm 1.97)}$ & & & \\
\hline & Shoot number per explant & & & & \\
\hline 440 & $2.4_{( \pm 0.06)}$ & $2.4_{( \pm 0.45)}$ & ns & ns & ns \\
\hline 1320 & $\begin{array}{r}2.2( \pm 0.30) \\
\text { Rooting }(\%)\end{array}$ & $2.7_{( \pm 0.70)}$ & & & \\
\hline 440 & 14.2 & 46.5 & ns & $P \leq 0.05$ & ns \\
\hline 1320 & 24.0 & 40.8 & & & \\
\hline & Apical necrosis (\%) & & & & \\
\hline 440 & 21 & 51 & $P \leq 0.01$ & $P \leq 0.05$ & ns \\
\hline 1320 & 10 & 30 & & & \\
\hline & Hyperhydricity (\%) & & & & \\
\hline 440 & 23.0 & 30.0 & $P \leq 0.01$ & ns & ns \\
\hline 1320 & 6.0 & 1.3 & & & \\
\hline
\end{tabular}

Significance ( $P$-values) of the two-way ANOVA. $\mathrm{CaCl}_{2} \cdot 2 \mathrm{H}_{2} \mathrm{O}$ concentration and subculture as the two factors. Data represent means \pm standard error. 
The subcultures presented statistical differences for shoot length, rooting percentage and shoot-tip necrosis (Table 1). However, for the number of leaves, shoot number per explant and hyperhydricity percentage, there were no statistical differences (Table 1). The shoots cultured on the MS medium supplemented with $440 \mathrm{mg} \mathrm{L}^{-1}$ $\mathrm{CaCl}_{2} \cdot 2 \mathrm{H}_{2} \mathrm{O}$ presented severe hyperhydricity, exhibiting typical glassiness (Fig. 1). For both the subcultures, hyperhydricity was observed at the frequencies of 23 and $30 \% \quad\left(440 \mathrm{mg} \mathrm{L}^{-1}\right.$ $\mathrm{CaCl}_{2} \cdot 2 \mathrm{H}_{2} \mathrm{O}$ ). In contrast, only 6.0 and $1.3 \%$ of the shoots cultured on MS with $1320 \mathrm{mg} \mathrm{L}^{-1}$ $\mathrm{CaCl}_{2} \cdot 2 \mathrm{H}_{2} \mathrm{O}$ were hyperhydric (Table 1 ). These results demonstrated the calcium effect to reduce the hyperhydricity in L. angustifolia shoots. Similar results were observed in the studies on calcium deficiency in tissue cultures. It was shown that an increase in calcium in the medium reduced the hyperhydricity in several plant species (Sha et al. 1985).

The shoot-tip necrosis in L. angustifolia cultivated in vitro was characterized visually by a whiteness color (Fig. 1). The rates of shoot-tip necrosis were also higher in the medium containing $440 \mathrm{mg} \mathrm{L}^{-1}$ $\mathrm{CaCl}_{2} \cdot 2 \mathrm{H}_{2} \mathrm{O}$ (21 and $51 \%$ for the first and second subculture, respectively) than in the shoots cultured in the presence of $1320 \mathrm{mg} \mathrm{L}^{-1}$ $\mathrm{CaCl}_{2} \cdot 2 \mathrm{H}_{2} \mathrm{O}$ (10 and $30 \%$ for the first and second subculture, respectively) (Table 1). The high relative humidity of the gaseous atmosphere is commonly observed in tissue culture vessels and this factor alone probably results in a substantial depression of transpiration and creates conditions in which calcium related disorders might tend to develop in fast growing shoot tips (Abousalim and Mantell 1994). The absorption and the translocation of $\mathrm{Ca}$ through the plant tissues are dependent of the mass flow and it is limited by the low transpiration of the explants cultivated in the flasks under high relative humidity, reducing the transport of ions of low mobility as the calcium (Sha et al. 1985). This symptom of shoot tip necrosis caused by calcium deficiency occurs in both ex vitro and in tissue culture (Sha et al. 1985; Piagnani et al. 1996).

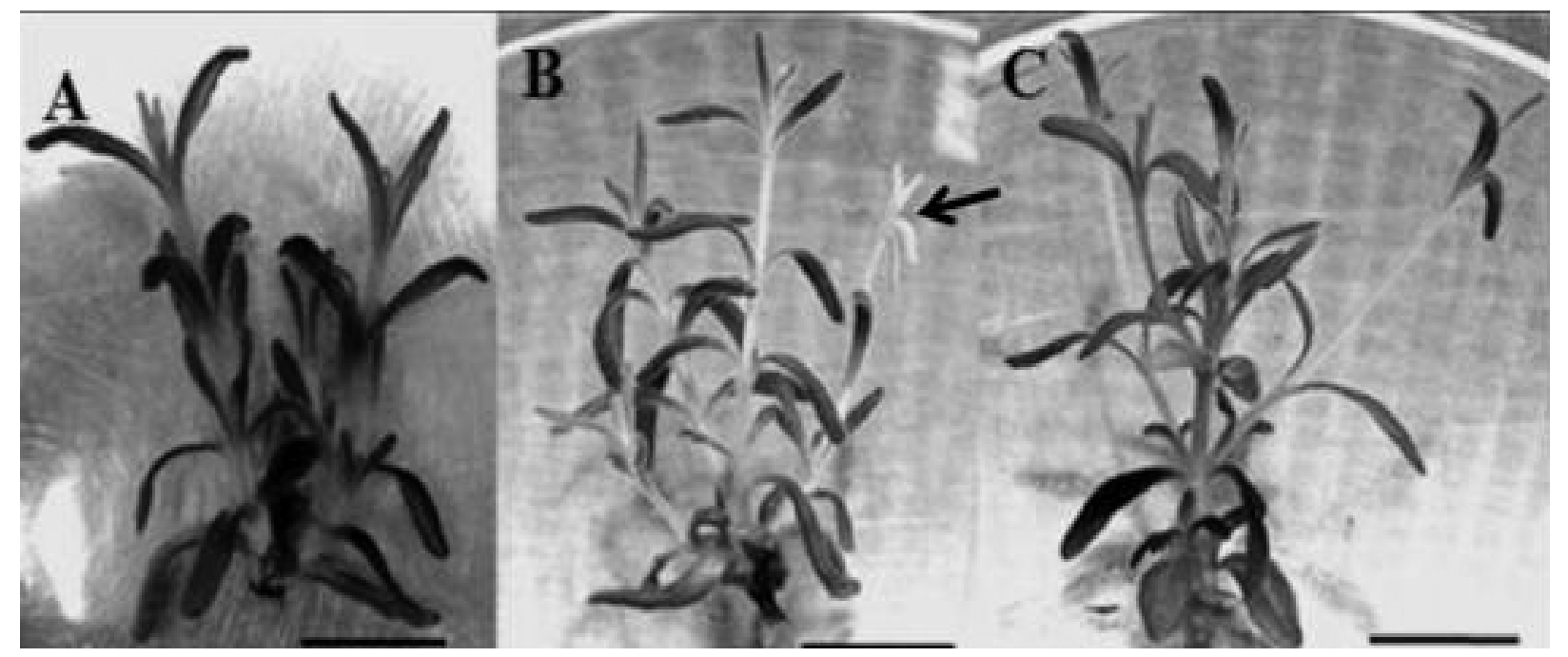

Figure 1 - Shoots of Lavandula angustifolia cultivated in vitro. (A) Hyperhydric shoots, (B) Shoots with tip necrosis (arrow) and (C) Normal shoot. Bars: $10 \mathrm{~mm}$.

Characteristic symptoms of calcium deficiency include necrosis of young meristematic regions, such as the tips of roots or young leaves, where cell division and wall formation are most rapid. Necrosis in slowly growing plants may be preceded by a general chlorosis and downward hooking of the young leaves. Young leaves may also appear deformed. The root system of a calcium-deficient plant may appear brownish, short, and highly branched. Severe stunting may result if the meristematic regions of the plant die prematurely (Taiz and Zeiger 2006).

Calcium is associated to the processes such as membrane structure and function, ions uptake, 
reactions with growth regulators and enzymatic activation (via calmodulin) (Malavolta et al. 1997). The structural function of calcium is characterized by the use in the synthesis of new cell walls, particularly the middle lamellae that separate newly divided cells (Taiz and Zeiger 2006).

Shoots of L. angustifolia cv. Provence Blue grown on $1320 \mathrm{mg} \mathrm{L}^{-1} \mathrm{CaCl}_{2} \cdot 2 \mathrm{H}_{2} \mathrm{O}$ had the highest $\mathrm{Ca}^{2+}$ content (Fig. 2). Calcium uptake was mainly localized in the basal and middle portion of shoots (Fig. 2). The data showed that calcium had the tendency to accumulate in the basal and middle part of the shoot with a very slow movement to the apex and probably therefore, the shoots were affected by tip necrosis as a consequence of uptake deficiency.

The transversal section of the non-hyperhydric and hyperhydric leaves showed uniserial epidermis with thin walls and stomata on both the surfaces. The observations revealed that the anatomy in non-hyperhydric leaves presented smaller and more juxtaposed cells and a more differentiated vascular system when compared with hyperhydric leaves (Fig. 3A-B). The leaves of hyperhydric shoots and non-hyperhydric shoots were characterized by the drastically reduced palisade tissue. The mesophyll appeared spongy with large intercellular spaces (Fig. 3), which were similar in the in vitro cultivated leaves of Eucalyptus benthamii (Brondani et al. 2012).

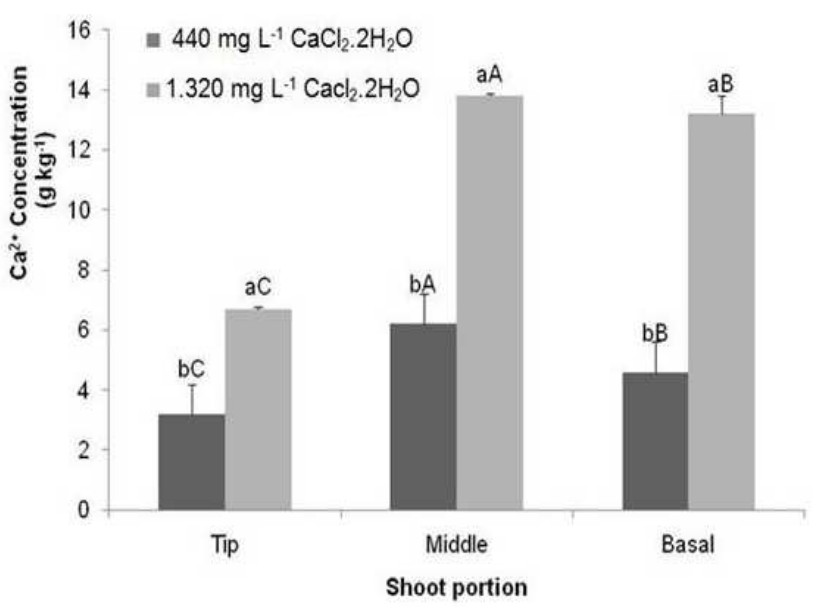

Figure 2 - Effect of the $\mathrm{CaCl}_{2} \cdot 2 \mathrm{H}_{2} \mathrm{O}$ concentration on tissue $\mathrm{Ca}^{2+}$ content in different shoot portions of Lavandula angustifolia cv. Provence Blue. Means (bars) with the same letter are not different in Duncan's test $(P \leq$ 0.05). Lowercase letters: $\mathrm{CaCl}_{2} \cdot 2 \mathrm{H}_{2} \mathrm{O}$ concentrations; and uppercase letters: shoot portions (tip, middle and basal parts). Bars represent the standard error of the mean.
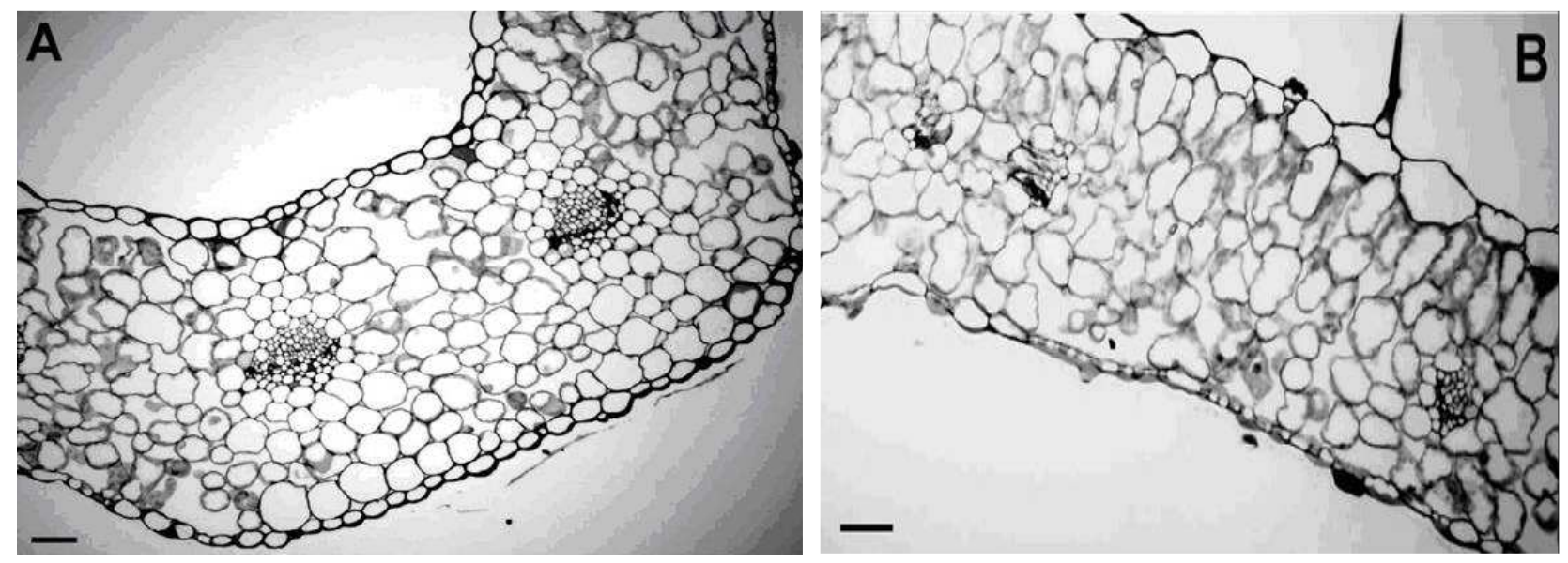

Figure 3 - Transversal sections of leaves from shoots of Lavandula angustifolia cv. Provence Blue cultured in vitro after 40-d. (A) Non-hyperhydric leaves (B) Hyperhydric leaves. Bars $500 \mu \mathrm{m}$.

The stomata of non-hyperhydric and hyperhydric leaves displayed normal morphology (Fig. 4B-F). Louro et al. (1999) also found same basic structure (normal stomata in non-hyperhydric and hyperhydric leaves) in E. grandis W. Hill ex Maiden x Eucalyptus urophylla S. T. Blake. Due to the high density of trichomes on the lower surface of the in vivo leaf, the detailed study of the stomata was not possible (Fig. 4A-B).

Trichomes were observed on the abaxial and adaxial surfaces of both types of the leaves, in vivo and in vitro, but in smaller quantities in vitro (Fig. 
4A-F). Taha and Haron (2008) suggested that the anatomical and morphological differences observed in in vivo and in vitro leaves were due to the differences of the environment of the plants. Trichomes have a function of the defense and protection in the plants, and, as the in vitro environment lacks predators, it is possible that in in vitro tissues there are not signaling to produce a high number of trichomes.

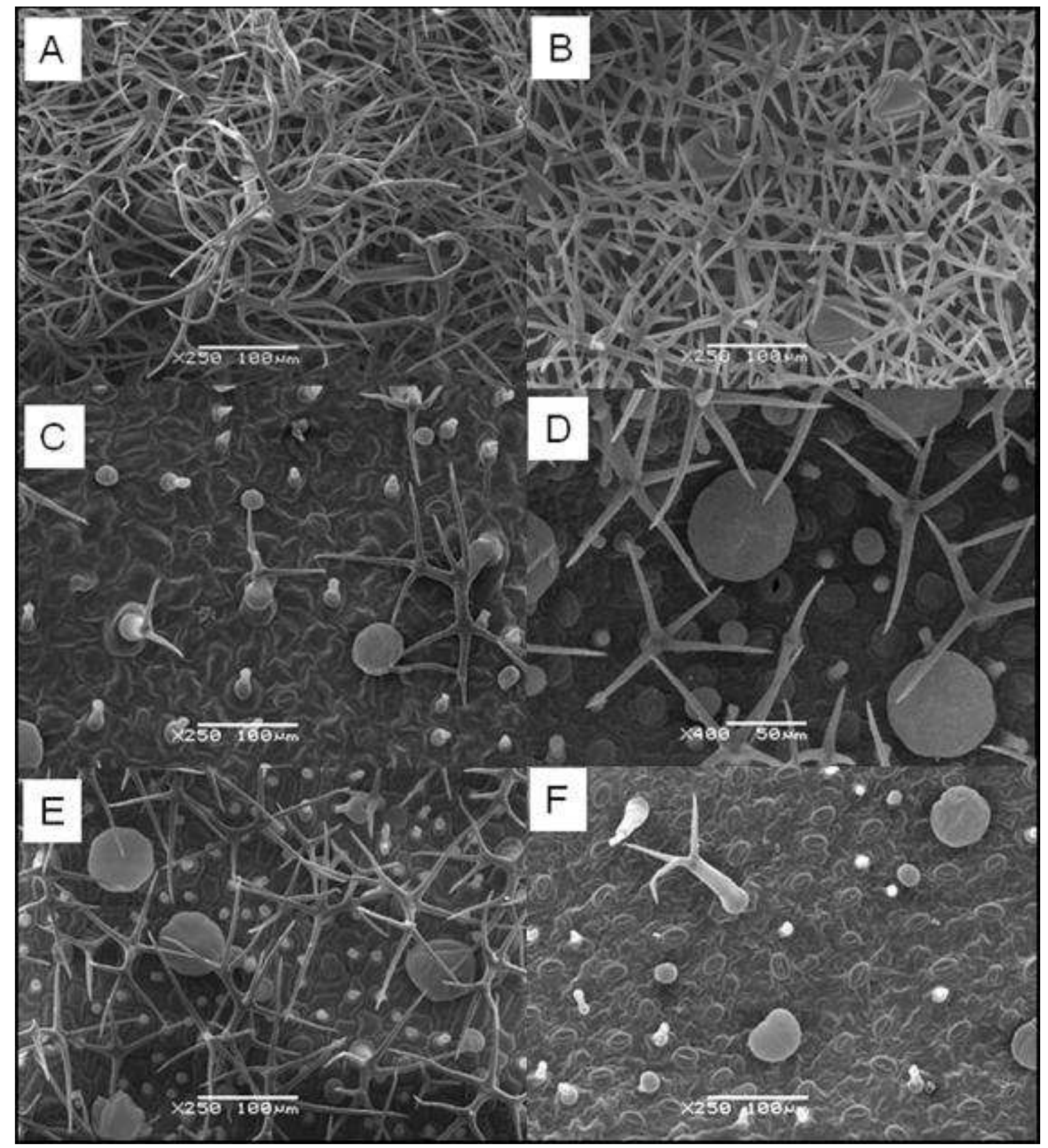

Figure 4 - Scanning electron microscopy of leaf blade surfaces of Lavandula angustifolia cv. Provence Blue. (A) Adaxial surface of in vivo leaf (second fully expanded leaf from the apical meristem). (B) Abaxial surface of in vivo leaf (second expanded fully leaf from the apical meristem). (C) Adaxial surface of in vitro non-hyperhydric leaf. (D) Abaxial surface of in vitro non-hyperhydric leaf. (E) Adaxial surface of in vitro hyperhydric leaf. (F) Abaxial surface of in vitro hyperhydric leaf. 


\section{CONCLUSIONS}

It was concluded that the increasing $\mathrm{CaCl}_{2} \cdot 2 \mathrm{H}_{2} \mathrm{O}$ level $\left(1320 \mathrm{mg} \mathrm{L}^{-1}\right)$ in the culture medium increased tissue $\mathrm{Ca}^{2+}$ content and decreased the hyperhydricity. Shoot-tip necrosis also decreased in the medium containing $1320 \mathrm{mg} \mathrm{L}^{-1}$ $\mathrm{CaCl}_{2} \cdot 2 \mathrm{H}_{2} \mathrm{O}$, but it did not occur in the second subculture. The middle and basal portion tissue had higher $\mathrm{Ca}^{2+}$ content higher than apical portion. In non-hyperhydric tissues, there were smaller and more juxtaposed cells. Scanning electron microscopy of the leaves demonstrated that the quantity of trichomes on in vitro leaf surface was smaller than the quantity of trichomes on in vivo leaf surface.

\section{REFERENCES}

Abdoli M, Moieni A, Dehghani H. Effects of cultivar and agar concentration on in vitro shoot organogenesis and hyperhydricity in sunflower (Helianthus annuus L.). Pak J Bot. 2007; 39: 31-35.

Abousalim A, Mantell SH. A pratical method for alleviating shoot-tip necrosis symptoms in in vitro shoot cultures of Pistacia vera cv. Mateur. J Hortic Sci. 1994; 69: 357-365.

Andrade LB, Echeverrigaray S, Fracaro F, Pauletti GF, Rota L. The effect of growth regulators on shoot propagation and rooting of common lavender (Lavandula vera DC). Plant Cell Tissue Org Cult. 1999; 56: 79-83.

Brondani GE, Wit Ondas HW, Baccarin FJB, Gonçalves AN, Almeida M. Micropropagation of Eucalyptus benthamii to form a clonal micro-garden. In Vitro Cell Dev Biol Plant. 2012; 48: 478-487.

Calvo MC, Segura J. In vitro propagation of lavender. HortScience. 1989; 24: 375-376.

Carvalho DC, Lopes da Silva AL, Schuck MR, Purcino M, Tanno GN, Biasi LA. Fox grape cv. Bordô (Vitis labrusca L.) and grapevine cv. Chardonnay (Vitis vinifera L.) cultivated in vitro under different carbohydrates, amino acids and 6-Benzylaminopurine levels. Braz Arch Biol Technol. 2013; 56: 191-201.

Debergh P, Aitken-Christie J, Cohen D, Grout B, Von Arnold S, Zimmerman R, et al. Reconsideration of the term 'vitrification' as used in micropropagation. Plant Cell Tiss Organ Cult. 1992; 30: 135-140.

Echeverrigaray S, Basso R, Andrade LB. Micropropagation of Lavandula dentata from axillary buds of Field-grown adult plants. Biol Plantarum. 2005; 49: 439-442.

Feder N, O’Brien TP. Plant microtechnique: some principles and new methods. Am J Bot. 1968; 55: 123-142.
Gaspar T, Kevers C, Bisbis B, Franck T, Crèvecoeur M, Greppin H, et al. Loss of plant organogenic totipotency in the course of in vitro neoplastic progression. In Vitro Cell Dev Biol Plant. 2000; 36: 171-181.

Gras MC, Calvo MC. Micropropagation of Lavandula latifolia through nodal bud culture of mature plants. Plant Cell Tiss Organ Cult. 1996; 45: 259-261.

Johansen DA. Plant Microtechnique. New York: Mac Graw Hill Book; 1940.

Jordan AM, Calvo MC, Segura J. Morphogenesis in callus and single-cell cultures of Lavandula latifolia Medicus. J Hortic Sci. 1990; 65: 49-53.

Lis-Balchin M, Hart S. Studies on the mode of action of the essential oil of lavender (Lavandula angustifolia P. Miller). Phytother Res. 1999; 13: 540-542.

Louro RP, Santos AV, Machado RD. Ultrastructure of Eucalyptus grandis x Eucalyptus urophylla. I. Shoots cultivated in vitro in multiplication and elongationrooting media. Int J Plant Sci. 1999; 160: 217-227.

Machado MP, Biasi LA, Reinhart V, Santos GD. Redução da necrose apical e hiperidricidade de plantas de Lavandula angustifolia Mill. cultivadas in vitro. Plant Cell Cult Micropropag. 2010; 6: 18-25.

Machado MP, Silva ALL, Biasi LA. Effect of plant growth regulators on in vitro regeneration of Lavandula dentata L. shoot tips. J Biotec Biodivers. 2011; 2: 28-31.

Malavolta E, Vitti GC, Oliveira SAD. Avaliação do estado nutricional das plantas. Piracicaba: Associação Brasileira para Pesquisa da Potassa e do Fosfato; 1997.

Marschner H. Mineral nutrition of higher plants. London: Academic Press; 1995.

McCown BH, Sellmer JC. General media and vessels suitable for woody plant culture. In: Bonga JM, Durzan DJ, editors. Cell and tissue culture in forestry. Dordrecht: Martinus Nijhoff; 1987. p 4-16.

Murashige T, Skoog F. Revised medium for rapid growth and bioassays with tobacco tissue culture. Physiol Plant. 1962; 15: 473-497.

O'Brien TP, Feder N, McCully ME. Polychromatic staining of plant cell walls by toluidine blue. Protoplasma. 1964; 59: 368-373.

Oliveira Y, Pinto F, Silva ALL, Guedes I, Biasi LA, Quoirin M. An efficient protocol for micropropagation of Melaleuca alternifolia Cheel. In Vitro Cell Dev Biol Plant. 2010; 46: 192-197.

Piagnani C, Zocchi G, Mignani I. Influence of $\mathrm{Ca}^{2+}$ and 6-benzyladenine on chestnut (Castanea sativa Mill.) in vitro shoot-tip necrosis. Plant Sci. 1996; 118: 8995.

Qiguang Q, Read PE, Fellman CD, Hosier MA. Effect of medium constituents and rooting regime on in vitro culture of Castanea mollissima and $C$. dentata. HortSci. 1985; 20: 593.

Quazi MH. In vitro multiplication of Lavandula spp. Ann Bot-London. 1980; 45: 361-362. 
Scheidt GN, Silva ALL, Oliveira Y, Costa JL, Biasi LA, Soccol CR. In vitro growth of Melaleuca alternifolia Cheel in bioreactor of immersion by bubbles. Pak J Bot. 2011; 43: 2937-2939.

Sha L, McCown BH, Peterson LA. Occurrence and cause of shoot-tip necrosis in shoot cultures. J Amer Soc Hort Sci. 1985; 110: 631-634.

Silva ALL, Costa JL, Alcantara GB, Carvalho DC, Schuck MR, Biasi LA, et al. Micropropagation of Nidularium innocentii Lem. and Nidularium procerum Lindm. (Bromeliaceae). Pak J Bot. 2012; 44: 1095-1101.

Silva ALL, Rodrigues C, Costa JL, Machado MP, Penha RO, Biasi LA, et al. Gibberellic acid fermented extract obtained by solid-state fermentation using citric pulp by Fusarium moniliforme: Influence on Lavandula angustifolia Mill. cultivated in vitro. Pak J Bot. 2013; 45: 2057-2064.
Taha RM, Haron NW. Some morphological and anatomical studies of leaves and flowers of Murraya paniculata (Jack) Linn. in vivo and in vitro. Pak J Biol Sci. 2008; 11: 1021-1026.

Taiz L, Zeiger E. Plant physiology. $3^{\text {rd }}$ Edition, Sunderland MA: Sinauer Associates Inc.; 2006.

Ziv M. Vitrification: morphological and physiological disorders of in vitro plants. In: Debergh PC, Zimmerman RH, editors. Micropropagation: technology and application. Dordrecht: Kluwer Academic Publishers; 1991. p. 45-69.

Zuzarte MR, Dinis AM, Cavaleiro C, Salgueiro LR, Canhoto JM. Trichomes, essential oils and in vitro propagation of Lavandula pedunculata (Lamiaceae). Ind Crop Prod. 2010; 32: 580-587. 